\title{
INTERFACES GRÁFICAS DE ENTRADA E SAÍDA DA eGs (electrical GEOPHYSICS suite)
}

\section{Rodrigo Erasmo da Conceição Silva}

Orientador: Dr. Luiz Rijo (UFPA)

136 p. - Dissertação (Mestrado) - Defesa 15.04.2005

RESUMO. Apresentamos uma interface gráfica para o programa eGs (electrical GEOPHYSICS suite) usado na modelagem e interpretação de dados elétricos e eletromagnéticos na exploração geofísica. Esta dissertação corresponde a parcela do programa que trata das interfaces de entrada de dados de modelos geoelétricos bi e tridimensionais e das interfaces de apresentação dos resultados da modelagem como também dos dados observados. 0 programa contém interfaces para criação, modificação e visualização de modelos geoelétricos bi e tridimensionais, e para apresentação da resposta do modelo através de gráficos e imagens. Este trabalho resultou num programa com diversas opções para alterar a geometria e as propriedades físicas do modelo geoelétricos e recursos de visualização para facilitar a interpretação de dados geofísicos. A interface gráfica pode ser usada para criar modelos geoelétricos dos métodos elétrico ou eletromagnético mais usados e analisar as respostas dos modelos e de dados observados em campanha de campo. 0 programa é suficientemente flexível de modo que novas interfaces gráficas de outros métodos elétricos e eletromagnéticos podem ser facilmente implementadas.

ABSTRACT. We present a graphic interface for the program eGs (electrical GEOPHYSICS suite) used for modeling and interpretation of electric and electromagnetic data in geophysical exploration. This master degree dissertation corresponds the portion of the program that treats the interfaces for bi and three-dimensional input data of geoelectrical models together with interfaces for the presentation of the modeling results and for the presentation of observed data as well. The program contains interfaces for creation, modification and visualization of bi and threedimensional geoelectrical models and for illustrations of the calculated results through graphs and images. This work gives a program with several options to alter the geometry and the physical properties of the geoelectrical models, including facilities for three dimensions visualization in order to help geophysical data interpretation. The graphic interfaces can be used to create geoelectrical models associated with the most used electric and electromagnetic geophysical methods and to analyze the answers obtained by numerical modeling associated with different types of observed data in field campaign. The program is sufficiently flexible so that new graphic interfaces of other electric and electromagnetic methods can be implemented easily. 